\title{
THE AMERICAN MUSEUM OF NATURAL HISTORY
}

\section{The Museum and Nature Study \\ in the Public Schools}

$$
5.07(74.71)
$$

\section{HENRY FAIRFIELD OSBORN}

President of the Board of Trustees

$$
\text { AND }
$$

\section{GEORGE H. SHERWOOD}

Curator of the Department of Public Education

Miscellaneous Publications of the American Museum of Natural History, No. 3

NEW YORK 
$38.142578-\operatorname{meg}^{23}$ 


\section{The Museum and Nature Study in the Public Schools}

The Committee on Studies and Text-Books of the Board of Education has presented to the Board a report which recommends drastic changes in the course of study for the elementary schools. The most serious of these changes is the recommendation that Nature Study be dropped from the curriculum as a separate subject, and that it be taught partly in connection with the English work and partly with the geography work.

The attitude of the American Museum of Natural History on this question is set forth in a letter which Professor Henry Fairfield Osborn, President of the American Museum, sent to the Honorable Thomas W. Churchill, President of the Board of Education, on February 6, I9I3, of which the following is an extract:

As President of the American Museum of Natural History, I am deeply interested in the subject of Nature Study in the Public Schools, and I trust, in connection with the changes which are now under consideration by your Board, that the great progress that has been made in our city in this important division of study will not be arrested through any reactionary advice or influence.

As a careful student of education during the last thirty-two years, and as a teacher in Princeton and Columbia Universities for thirty years, I have watched the development of nature study with great interest. It arose, as you know, largely from the influence of Agassiz in this country and of Huxley in England, and fills a place in the scheme of education which it is impossible to fill in any other way.

The Trustees of this institution for years have coöperated with the Board of Education, and a marked copy of the Preliminary Report which I have just made to the Trustees, together with a copy of our special educational number of the Report issued last 
year, will give you an idea of the very rapidly in creasing influence of the Museum and of nature study in the schools. The teachers whom I have observed here practically conducting their class work in our Museum halls are intelligent in their methods and very enthusiastic in the guidance of children of all ages. Step by step a great system of coöperation has been built up between the regular course work in the schools and the visual instruction in the Museum, until the City of New York now affords the most brilliant example in the world of extension to the school system of all the resources of a great museum.

The Board of Education of Chicago has recently visited the Museum with a view to the introduction in that city of some of our methods. Mr. Norman W. Harris, of Chicago, has given $\$ 250,000$ to carry this plan into effect.

The Imperial German Commission, which visited this city last spring, informed me that the nature study system of coöperation between the Museum and the schools was, it believed, the most complete in existence, considering the very large scale of the work carried on.

The text-books which have recently been prepared by nature study teachers in the city have taken full advantage also of the resources of both the American and Brooklyn Museums. They are models of their kind.

The greatest pleasure which I derive from my arduous life in the administration of the Museum is watching the vast and increasing number of school children, with and without their teachers, who visit the institution for inspiration and whose serious study and observation of the various objects are very noticeable. The influence upon the life of these pupils is incalculable. The lessons also regarding health and the fundamental principles of biology, which are taught in such volumes as Peabody's Elementary Biology-Animal and Human, recently issued by him at the Morris High School, are invaluable.

The Trustees of the American Museum invite the coöperation of the Board of Education and will welcome any improvement in the present system which may be found practical. 
We have just added to our Public Educational Staff Mr. G. Clyde Fisher, a graduate of Johns Hopkins, with a view to still more active coöperation with the nature study system of the schools. Our Curator of Public Education, Mr. George H. Sherwood, was trained in the public schools of Providence, before coming to his present position.

It is absolutely essential that nature study should be objective and not from books-in fact, this is the distinctive value of nature study. Our circulating museums, which now reach over one million pupils, are designed to carry as many objects as possible to the schools. The children who come here are also given opportunities of direct objective study on a larger scale.

At a public hearing of the Committee on Studies and TextBooks on February I8, I9I3, Mr. George H. Sherwood, Curator of the Department of Public Education, represented the American Museum and made the following statement of the relations of the Museum to the educational system of the City and its active participation in the Nature Study work:

The American Museum of Natural History has been from its beginning-thirty-four years ago-a strong advocate of Nature Study, and, with the introduction of this subject in the curriculum of the city schools, has placed selections from its wealth of material at the disposal of the teachers.

One of the chief defects in the present course of nature study in the New York public schools is the lack of provision for supplying the teachers with all the necessary material called for in the Syllabus.* The "Syllabus" refers to a veritable host of specimens, but these can be obtained only at the expenditure of great energy and ingenuity on the part of the teachers. It is no wonder, then, that when nature study was introduced into the schools, many of the teachers appealed to the Museum, and in this emergency the Museum came forward and offered its assistance.

With the approval of your superintendents, we have developed a system of circulating natural history

* Course of Study and Syllabuses in Geography, Nature Study and Elementary Science for the Elementary Schools of the City of New York, rgo8. 
collections which are designed to place in the hands of the teachers specimens called for in the syllabus of nature study.

The work began in 1903 with ten small cases of birds; to-day more than five hundred cabinets, including birds, insects, minerals and woods, are in use in the schools. Without expense to the Board of Education this material is sent to the very city limits -to City Island on the north; to Canarsie and Coney Island on the east and south, and to remote districts in Staten Island.

The first year, I903, only a few thousand children studied the collections; last year more than a million were reached. The first year fewer than a hundred schools were supplied; to-day there are nearly five hundred on our list.

The Trustees devote from $\$ 10,000$ to $\$ 15,000$ a year of their funds to this work and are prepared to further extend it.

As already stated, the work is carried on without expense to the Board of Education and is quite outside of any obligation imposed on the Museum by its contract with the City, but the Trustees believe that the primary function of the Museum is educational and are very glad to coöperate with the public school system in this way.

As to the practical results of this nature study, the principals and teachers are far better qualified to judge than are we, but we do see the results in increasing attendance at the Museum; in the large numbers of children that may be seen almost daily in the exhibition halls; and in the return of these children, with their parents, on holidays and Sundays.

We are firm believers in nature study. It stimulates the imagination; it exercises all the special senses-hearing, taste, sight, smell and touch; it is especially suited to developing independent judgment, the correctness of which can be tested. In all instruction from books, the child is dependent upon the authority of others. Nature study develops in the child a keen sympathy for all living things; and, most important of all, there is no subject so well suited to training the powers of accurate observation. 
For this purpose alone we feel that nature study is well worth while.

It may be that the present course of nature study needs simplification-perhaps radical revision-but to drop the subject entirely from the curriculum would be distinctly a retrogressive step.

A resumé of the educational work of the Museum for the year I 912 is presented in the following extracts from the sixth Annual Report of President Osborn to the Board of Trustees:

Although the location of the Museum is still far from the center of population, the attendance for the year was 846,963 , an increase of 122,822 over the figures for 1911 . The general lectures were attended by 80,249 persons; the children's lectures and opportunities for special study attracted 49,872 ; while the circulating collections, which are sent out daily from our doors, reached I, 275,890 school children, the largest number yet recorded. This system of circulating collections has been extended to some of the schools of New Jersey. It is also interesting to note that the colleges and universities of the country are making increasing use of our exhibition halls for purposes of instruction, professors and students from the colleges of New England and the Middle States making special journeys to the Museum for this purpose.

The total number reached by the Museum's Extension System is shown by the following statistics:

\begin{tabular}{|c|c|c|c|c|c|c|c|}
\hline I905 & I 906 & I907 & Ig08 & I 909 & IgIO & I9I I & 1912 \\
\hline $\begin{array}{l}\text { Board of Educa- } \\
\text { tion Lectures... 42,2 I } 2\end{array}$ & 45,000 & 35,068 & $43,3^{86}$ & 28,402 & 43,549 & 40,067 & 52,855 \\
\hline $\begin{array}{l}\text { Lectures to } \\
\text { School Children } \\
\text { and Children's } \\
\text { Room......... 35,000 }\end{array}$ & I 7,787 & 29,688 & $28,36 \mathrm{I}$ & 27,524 & I5,6ro & 29,935 & 39,624 \\
\hline $\begin{array}{l}\text { Classes visiting } \\
\text { the Museum for } \\
\text { General Study.. I I, } 000\end{array}$ & 6,813 & 7,795 & In, 8 I 8 & $8,7 \times 2$ & 9,284 & 9,444 & $10,24^{8}$ \\
\hline $\begin{array}{l}\text { Meetings of Sci- } \\
\text { entific Societies } \\
\text { and other Meet- } \\
\text { ings and Lec- } \\
\text { tures.......... } 35,28 \mathrm{t}\end{array}$ & 6,867 & $\mathrm{Ir}, 78_{4}$ & $\mathbf{r} 5,5^{87}$ & 27,369 & 15,712 & $\mathbf{r} 8,649$ & $28,3^{8} 4$ \\
\hline $\begin{array}{l}\text { General atten- } \\
\text { dance for all } \\
\text { purposes....... } 5_{5,489} 9\end{array}$ & 476,133 & 537,894 & $\mathbf{1}, 043,5^{82}$ & $839, \mathbf{I} 4 \mathrm{I}$ & $6 \mathrm{r}_{3:} \mathrm{r}_{52}$ & $724, x_{4} I$ & 846,963 \\
\hline $\begin{array}{l}\text { Number of Pupils } \\
\text { reached by Cir- } \\
\text { culating Collec- } \\
\text { tions...........375,000 }\end{array}$ & 800,000 & 725,000 & $575,80 \mathrm{r}$ & 922,512 & 839,089 & $1,253,435$ & $\mathbf{I}, 275,890$ \\
\hline
\end{tabular}


The activities of the Museum's Department of Public Education for the year I9I2 are set forth in the following report of the Curator:

Department of Public Education.-It is the chief function of the Department of Public Education to assimilate the scientific data collected by other departments and present these facts in such a way that teachers can readily make use of them and children can easily understand them. By this means, we attempt to arouse in children and adults a keener interest in nature and outdoor life. The activities of the department during the year have been devoted to the improvement of present methods rather than to the development of new.

As in the past the principal means of contact between the Museum and the schools have been the circulating collections and the lectures, but certain special features have aided in strengthening the relations existing between the Museum and the educational system of the City. Of these special features, mention should be made of "Burroughs Day," the Third Annual Teachers' Day, and representation before the Committee on School Inquiry of the Board of Estimate and Apportionment.

On April ro, in celebration of the seventy-fifth birthday of John Burroughs, more than 300 pupils from the lower east side, members of the Burroughs Clubs of Public Schools Nos. I 5 and 188 , assembled at the Museum and under the direction of Miss Margaret Knox and Miss Ellen Phillips presented an original play which had for its theme the love of nature as revealed in Mr. Burroughs's writings. Mr. Burroughs was present as the guest of honor, and was greatly pleased by this tribute from the children, the majority of whom were of foreign parentage.

In pursuance of the plan adopted two years ago, the Annual Teachers' Day was held at the Museum on November 16. Brief addresses were made by Director Lucas, Dr. Gustave Straubenmüller and the Curator, which were followed by an illustrated lecture by Vilhjalmr Stefansson, "Among the Eskimo of Coronation Gulf and Vicinity." The programs of previous years had presented material and information regarding the 
work in the Museum and its relation to the schools. The particular theme of this year's program was the relation of the Museum's explorations to the work of teachers, this being concretely illustrated by Mr. Stefansson's discoveries in the North. There were about 700 teachers present and many expressed themselves as having spent a profitable and enjoyable afternoon at the Museum.

On May I7, the Curator represented the Museum at a meeting of the Committee on School Inquiry of the Board of Estimate and Apportionment, of which John Purroy Mitchel, President of the Board of Aldermen, is Chairman. The purpose of the meeting was to discuss the coördination of the various agencies in the City which were prepared to coöperate with the public educational system. The Curator outlined briefly the relation of the Museum to the schools.

The department was represented at the meetings of the British Museums Association, held in Dublin in July, by Director Lucas, who presented a paper on the educational work of the Museum.

The educational methods of the Museum continue to receive attention from educators at home and abroad. In April the Imperial German Commission visited the Museum for the express purpose of studying our methods, and more recently Mrs. Ella Flagg Young, Superintendent of Schools of Chicago, and a Committee from the Chicago Board of Education made a critical examination of the work of the department with a view to introducing similar methods in the Chicago schools.

Museum Extension to the Schools and Libraries. - It is probable that no branch of the department's work is more practical or exerts a wider influence than the circulating collections. Through them, nature study material is placed in the hands of the teachers in the class rooms, and many thousands of pupils come in direct contact with it. The collections contain material referred to in the syllabus of nature study, and were originally prepared with such care that very little modification has been required. To the thirteen sets previously in use have been added the Public Health Folio 
which was prepared with the assistance and under the supervision of C.-E. A. Winslow, Curator of Public Health. The folio consists of a series of fifteen photographic enlargements illustrating the spread of disease and its prevention. Twelve of these folios, each accompanied by an explanatory guide, have been added to the circulating collections, and are much appreciated, especially by the high school teachers. Two additional public health folios are being prepared under the supervision of Professor Winslow, and will be issued in I9I3.

The distribution of the regular circulating collections to the schools has progressed as usual, and has required the services of two messengers. During the year, 49 I schools have been on our list, as follows:

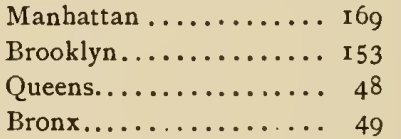

Richmond........... 2I

Corporate Schools....... 2I

Catholic Schools........ 4

High Schools and Colleges. 26

Statistics Relating to the Circulating Collections

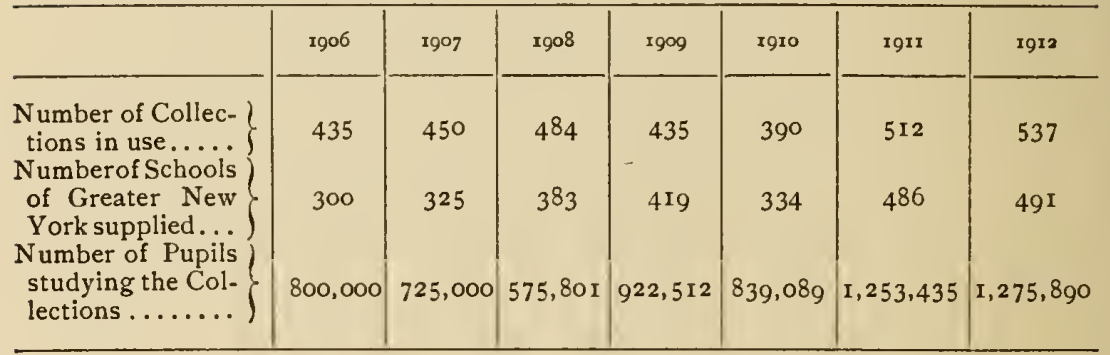

The total number of pupils reached is $1,275,890$, a larger number than in any previous year.

Fifty collections were rented to the Newark schools and were studied by $35,82 \mathrm{I}$ pupils, and in a few cases the collections have been loaned to other outside institutions.

Upon request of Miss Annie Carroll Moore, the Supervisor of Children's Rooms of the New York Public Libraries, the department has continued to supply various branch libraries of the city with ethnological collections illustrating the culture of the Indians, Chinese, Japanese, Koreans and Africans. 
Lectures to School Children.-Regular courses of lectures to school children have been given during the year. The new feature of the spring course was the introduction of moving picture films which added much to the interest of the children. For the most part these lectures were delivered by members of the Museum staff, but two very interesting talks on African travel were given by Carl E. Akeley, and one industrial lecture was given by Robert G. Weyh. We desire to acknowledge with thanks the services of these gentlemen. We also wish to express our thanks to the Canadian Pacific Railway Co., The Union Pacific Railroad Co., the Department of Street Cleaning of the City of New York, and the Shredded Wheat Co., for their courtesy in generously allowing us to use their lantern slides and moving picture films in our lectures on industries.

The experiences of the past two years indicated the desirability of a change in the schedule of lectures. In the past, the regular course consisted of nine lectures, each of which was given twice. In the fall series of this year, the eighteen lectures were divided into groups of six and not repeated. The first group was on American history and geography and was given on Mondays; the second was devoted to the geography of the world and occurred on Wednesdays; the Friday series treated of great American industries. Through consultation with teachers, these lectures were more closely correlated with the regular class-room work in these subjects. An increase in the attendance and many favorable comments from the teachers indicated the advisability of the change. In connection with this course and in coöperation with the department, the New York Public Library prepared and issued lists of books for the use of children. These lists were distributed at the Museum and the children were informed that they would find the books referred to in the children's libraries. The arrangements for these lectures were entrusted to Mrs. Roesler and Miss Wilds, and success is due in no small degree to their efficient work.

The attendance at the spring course was 15,328 ; at the fall course, 16,601 , a total of 31,929 . This is 9,132 more than attended similar lectures in I9II. Many of the lectures were 
so popular that the applications for seats were greatly in excess of the capacity of the auditorium, and in a few instances lectures were repeated in order to relieve the disappointment of teachers and children.

In addition to these regular lectures, many special lectures were given to classes from the elementary and high schools. Increasing numbers of teachers have used the lantern slides and class rooms, and it is a common occurrence to see pupils busily studying the bird groups or insects with notebook and pencil. The number utilizing the Museum in this way is registered as 10, 248 .

The increase in the attendance at the children's lectures is gratifying, but in this connection new difficulties of transportation have been brought to light. The fact that the journey to the Museum makes many of the pupils car-sick, so unused are they to travel, the severe tax on the energy of the teachers and the cost of transportation have raised the question of arranging for lectures at school centers. While this cannot be done at present, owing to the many demands already made on our staff, the desirability of such a plan is apparent.

Through the generosity of Henry Phipps, there was placed at the disposal of the department a fund with which to pay the car fare of children who otherwise could not afford a trip to the Museum. This money has been expended in the interests of the crippled children and the special classes in the public schools. On December 16,366 crippled children were brought to the Museum and listened with genuine interest to African jungle stories told by Carl E. Akeley. These were illustrated by lantern slides and motion pictures and the children thoroughly enjoyed them. This large number of children, many of whom could not even walk, were transported from the schools to the Museum and returned to their homes without accident.

The second lecture was for the special classes of Districts Nos. Io and II, which cover part of the congested portion of the lower west side. These classes are composed of children, chiefly of foreign parentage, who have not received sufficient education to secure "working papers" and who cannot afford 
even car fare for a trip to the Museum; 618 of these children listened to a lecture by Mrs. Roesler on "The Great Industries and Natural Wonders of our Country." This was fully illustrated with motion pictures.

We wish to express our heartiest thanks to Mr. Phipps for this gift which enabled us to give so much pleasure to these children.

General Lectures. - The general lectures have been more varied than usual and have attracted much attention. They have included a spring and a fall course for Members on Thursday evenings, the regular series under the auspices of the Board of Education, free lectures on public holidays, special lectures under the auspices of the New York Academy of Sciences and Affiliated Societies, lectures in conjunction with the American Scenic and Historic Preservation Society and a special course of lectures for Members on the Antiquity of Man.

So great was the popularity of Paul J. Rainey's lecture on lion hunting in the spring Members' Course that four thousand people had to be turned away. Later this lecture was repeated twice in the same evening by Carl E. Akeley for the benefit of Members.

On account of the widespread interest in the origin of man and the recent discovery of prehistoric remains, a special course of lectures was arranged on the Antiquity of Man. These lectures were designed to present a popular epitome of the present knowledge of this subject. The course was opened by President Osborn and proved of great public interest.

Children's Room.-The Children's Room was open regularly on Wednesdays and Saturdays during the spring and early summer. The attendance for the period was I, ro5. The room has been closed since July owing to necessary changes that were being made and from the fact that the instructor's time has been occupied with other duties in the department.

WORK FOR THE BLIND.--Through the Jonathan Thorne Memorial Fund we have been able again to extend special 
privileges to the blind. Special lectures have been arranged for children and adults, and collections adapted for their use have been placed at their disposal. Particular attention has been given to systematizing the work for the blind. These people have shown great timidity about coming to the Museum, which in a measure explains the small attendance; but progress has been made in overcoming this difficulty. Spring and fall courses of talks on zoölogy and anthropology were given by Mrs. Roesler and Miss Wilds to the blind pupils of the public schools and similar courses for adults from the institutions for the blind. These were fully illustrated with specimens which could be handled. The attendance of pupils was I54; of adults 70 . The work with the blind has been very interesting and has seemed to be a real source of pleasure to the people reached. They have been very attentive to the talks, eager for information and reluctant to have the story hour over.

A part of the income of the Jonathan Thorne Memorial Fund has been expended in paying the transportation of the blind to the Museum and for the preparation of small models to be sent to the blind pupils in the public schools, and we have io giraffes, ro camels and to hippopotamuses ready for use; I 2 relief maps of the world are nearly finished.

Collections of Indian, Eskimo and Japanese material have been sent to the classes for the blind in the public schools of Newark and Jersey City.

Photography and Cataloging. - The more successful the Museum expeditions, the greater is the burden placed on the division of photography. Especially during the past year when the scope and success of the expeditions have been great, the tax on this department has been unusually severe. Remarkable progress has been made in the routine photographic work, which has been carried on by one man unassisted. The photographer has displayed great ingenuity and efficiency in mastering the many difficulties involved in the special photographic work necessary in connection with the preparation of backgrounds for groups.

During the year the photographer has made 4,857 prints, I,760 slides, 955 negatives, 339 enlargements and 33 trans- 
parencies, but large as these numbers are, they are no indication of the labor involved in producing the results - desired.

Through the faithful and efficient work of Miss Muenchehofe, the reference file of photographs grows apace. This file now numbers 29,848 prints. The file of negatives numbers 23,88 I.

It has been stated repeatedly that the Museum possesses a collection of 35,000 lantern slides, but it has never been possible to make the fullest use of this valuable material since it is uncatalogued. A beginning has now been made on this important work. A new system of filing based on the Dewey Decimal System is being developed, which when completed will enable one to locate quickly slides on any subject desired. Nearly 2,000 slides have already been arranged in this file.

Accessions. - The principal accessions for the year are a collection of about r 50 birds' skins from Miss Evelyn Purdie and a collection of minerals, rocks, shells and birds' eggs from Clinton G. Abbott. Gifts from Charles Bohem, Mrs. H. S. Dewey, Miss Annie Miller and Arthur E. Krause have helped in beautifying the Children's Room. G. Seymour Willson kindly loaned us a set of negatives of gold mining in South America from which prints were made. 



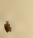





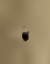

3

:

,

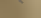

11.

1

,

. 
